\title{
Background Concentration of Copper and Cadmium in Water from a High Industrialized and Urban Coastal System (Baixada Santista, Brazil)-Contribution to a Monitoring Program
}

\author{
Elisabete S. Braga ${ }^{*}$, Riso D. Ricardo² \\ ${ }^{1}$ Laboratory of Biogeochemistry of Nutrients, Micronutrients and Traces in the Ocean, Oceanographic Institute, \\ University of São Paulo, São Paulo, Brazil \\ ${ }^{2}$ Laboratoire des Sciences de l'Environnementmarin, Institut Universitaire Européen de la Mer, CNRS/IRD/UBO, \\ Plouzané, France \\ Email: ^edsbraga@usp.br, Ricardo.riso@univ-brest.fr
}

How to cite this paper: Braga, E. S., \& Ricardo, R. D. (2021). Background Concentration of Copper and Cadmium in Water from a High Industrialized and Urban Coastal System (Baixada Santista, Brazil)— Contribution to a Monitoring Program. Journal of Geoscience and Environment Protection, 9, 132-150.

https://doi.org/10.4236/gep.2021.91011

Received: December 30, 2020

Accepted: January 26, 2021

Published: January 29, 2021

Copyright $\odot 2021$ by author(s) and Scientific Research Publishing Inc. This work is licensed under the Creative Commons Attribution International License (CC BY 4.0).

http://creativecommons.org/licenses/by/4.0/ (c) (i) Open Access

\begin{abstract}
The Baixada Santista coastal region is well known in the context of the high atmospheric, soil and aquatic pollution levels derived from port, industrial, domestic and urban activities existent there, mainly in function of the $\mathrm{Cu}-$ batão industrial pole and port of Santos. The contamination by trace metals in this region is rarely measured in water column when compared with metal determinations in sediment studies. This study aims to evidence the levels of dissolved copper and total cadmium concentrations in estuarine and seawater waters using electrochemical analysis as a chronopotentiometric stripping polarography, which could improve the environmental monitoring program. The study was performed in the Bay of Santos reaching two estuarine channels (Santos and São Vicente Channels) in two tide periods in summer 2001. This region is influenced by terrestrial and anthropogenic inputs of trace metals to seawater. The results showed that dissolved copper and total cadmium in water presented the maxima concentrations of $45.4 \mathrm{nM}$ and $2.6 \mathrm{nM}$ respectively. They not reached the limits proposed by Brazilian Environmental Law (CONAMA), that indicate, as reference, a maximum of $123 \mathrm{nM}$ and $350 \mathrm{nM}$ for dissolved copper and total cadmium, respectively and, considering seawater coastal system (salinity $>30$, class 2 ) and also brackish water (class 2). Although the values were under the maximum recommended for each metal, the concentrations were not negligible in relation to the other polluted areas in the world. The values distribution along the system showed a progressive increase in direction to the inner part of the system that natu-
\end{abstract}


rally compromises the local biota whose is more exposed to the bioaccumulation processes, and this data corresponds to an important reference preterit value to the monitoring program. The trace metal bioaccumulation by mangrove vegetation and by the biota in the internal part of the estuarine channels increase the risk of the poorly population that living in the internal part of the estuary, used to the seafood consumption. The contribution of this study is important to guide the protective policies destined to recuperate the natural conditions of this system, mainly considering that in the decade 1980, there was a case of toxic contamination, causing hydrocephaly in newborns. It proves the existence of risks to the human health and to the balance of the ecosystem, even with the decrease of pollution after that, the environmental evaluation needs to know the background values to guide environmental protection.

\section{Keywords}

Dissolved Toxic Metals, Tide Variation, Chronopotentiometric Analytical Method, Metal Biogeochemical Cycles, Bay of Santos

\section{Introduction}

Trace metals are present naturally in the terrestrial crust and weathering process was the main way to transform the particulate into dissolved forms contributing to the enrichment of salt in the aquatic system as a part of its biogeochemical cycles. Beside natural trace metal input, nowadays the coastal seawater presents an important anthropogenic contribution as a result of industrial, urban and domestic activities. Fostner \& Wittman (1983) showed that metal contamination in coastal regions and marginal seas can be attributed to some factors as effluents discharge from urban and industrial activities, wastes from vessels, fluvial suspended and dissolved matter, atmospheric precipitation, and natural marine sources. Trace metal contamination follows rivers and estuaries pathways before reaching the coastal areas. In estuaries, the salinity gradient influences the partition between particulate and dissolved form and the trace metal concentration levels in water column (Windom et al., 1991; Turner et al., 2002; Waeles et al., 2004, 2005a, 2005b). Trace metal distribution is also modified by seasonal and local hydrodynamic conditions mainly in coastal areas. Since trace metal affinity to dissolved organic matter and particulate matter vary according to each metal species (Yeats \& Loring, 1991; Millward \& Glegg, 1997; Zwolsman \& van Eck, 1999; Fang \& Lin, 2002; Fang et al., 2006). In a particulate or dissolved forms, trace metal may be entrapped in estuary compartments or release from coastal into oceanic waters (Boutier et al., 1993). Estuarine system is a natural and probably a permanent way of anthropogenic effluent disposal into coastal regions (Braga, 2002). Gao et al. (2014) recommend the use of ecological modeling to investigate the trace metal in the Bohai Sea to contribute to providing funda- 
mental for the protection of the environment, however, the data of trace metals in water are rare to feed modelling techniques in estuaries.

The Brazilian coastline has been characterized in four regions with specific characteristics, which distinctly affect fate of trace metals (Pfeiffer et al., 1988). The Baixada Santista area, located in the coastal southeast region, is distinguished by intensive industrial and urban activities, and trace metal contamination has been widely observed (Braga et al., 2000; CETESB, 2001; Hypolito et al., 2016). In this area, the metal concentration in water assessment is very important because the hydrological system is exposed to waste discharges from dredge activities and inputs from industrial, port, domestic and urban effluents. Beside it, the aquatic environment is used by a large population number of residents and tourists for recreational, navigation and fishing purposes. According to Tommasi (1987), the main sources of pollution for the Baixada Santista area are contributions from: 1) the Billings water reservoir which receives wastes from the São Paulo city; 2) the Santos harbor, which is related to operational conditions and precarious sanitary installations; 3 ) the industrial site in Cubatão city, responsible for large amounts of effluents disposal; 4) the domestic waste discharge from Sao Vicente and Santos cities; and 5) garbage dump from local population. Braga et al. (2000) found that the Baixada Santista area still undergos degradation processes with impacts for the local aquatic biota development and with irreversible negative effect for human health. Boldrini \& Pereira (1987) showed very high levels of total metal concentration in water column with concentration factors above one thousand for local fishes. CETESB (2001) presented data for cadmium in water column with concentration values between 2 to 7 $\mu \mathrm{g} \cdot \mathrm{L}^{-1}$ (17 - $\left.62 \mathrm{nM}\right)$. Also, levels for copper presented values in a range of 3 - 30 $\mu \mathrm{g} \cdot \mathrm{L}^{-1}(47.2$ - $472 \mathrm{nM})$. The Brazilian environmental law limits concentration levels up to $0.040 \mathrm{mg} / \mathrm{L}(350 \mathrm{nM})$ and $7.80 \mu \mathrm{g} / \mathrm{L}(123 \mathrm{nM})$, respectively, for total cadmium and dissolved copper (CONAMA, 2005).

In the Baixada Santista region it is well known some of contamination sources for trace metals. Copper pollution is mainly related to urban waste disposal from the Cubatão city and the Pilões area, and from aquatic contaminated sediment. Cadmium contamination comes mostly from garbage leaching of the Pilões area, industrial waste related to petroleum refinery, paper factories (cellulose plants) and from aquatic contaminated sediment (CETESB, 2001). High level of cadmium in the aquatic system was possibly related to polluted sediment dredged from the estuary and irregular nearby disposal. Analyses of trace metals in estuarine local sediments also show high levels of contamination (Siqueira et al., 2005; Salaroli et al., 2018; Kim et al., 2016, 2017). Close to a steel factory, trace metal concentrations in sediments varying from $0.50 \mu \mathrm{g} / \mathrm{g}$ and up to $6.0 \mu \mathrm{g} / \mathrm{g}$ and from $0.41 \mu \mathrm{g} / \mathrm{g}$ up to $100 \mu \mathrm{g} / \mathrm{g}$ for cadmium and copper, respectively were observed (CETESB, 2001). The Environmental law for dredged material indicates the following ranges: $1.2-9.6 \mathrm{mg} / \mathrm{kg}$ for $\mathrm{Cd}$ and $34-240 \mathrm{mg} / \mathrm{kg}$ for $\mathrm{Cu}$ (CONAMA 344/04).

Dissolved metal analyses in seawater remains a challenging task and consi- 
dering few techniques available one finds the electrochemical stripping techniques, and especially chronopotentiometry, suited for trace metal studies due to its excellent detection and sensitivity (Pinheiro \& van Leeuwen, 2004). The stripping chronopotentiometry method involves a deposition step during which the target metal species is accumulated at the electrode surface. It is followed by reoxidation through application of a constant oxidizing current (stripping current), until full depletion and the analytical signal is the electrolysis time. The chronopotentiometric method is particularly suited to analyze estuarine and coastal waters from polluted areas as it is not directly affected by presence of organic matter (Waeles et al., 2004; Waeles et al., 2008).

Copper is biologically removed from seawater and used as micronutrient in some biochemical processes. In excess, it causes disruption of cells and negative effects in the biochemical reactions (Boyle et al., 1977; Bruland, 1980). In the Amazon zone, Boyle et al. (1982), showed field data along a line defined by the river water copper concentration of $24 \mathrm{nmol} \cdot \mathrm{Kg}^{-1}$ and the coastal ocean water concentration of $2 \mathrm{nmol} \cdot \mathrm{Kg}^{-1}$ with an essentially conservative behavior.

So far, there is not enough available information in literature about copper and cadmium concentrations in water column of the Santos and Sao Vicente channels and the Santos Bay obtained by direct method of determination without pre-concentration. Metal species in water constitute an important form in the metal biogeochemical cycle and represent one of its most bioavailable form to the biota assimilation and to bioaccumulation in the local trophic chain causing anomalies (Azevedo et al., 2013). This work intends to provide data of copper and cadmium in surface and bottom waters of the estuarine Channels and Santos Bay considering its distributions on the spring and dead tides observing the behavior in relation anthropogenic level of influence in the different sectors of the estuarine system and Bay of Santos. This information represents a record of one important preterit data to form the history of these dissolved metal dynamics in one of the most important industrialized areas of the Brazilian coast.

\section{Material and Methods}

\subsection{Study Area}

The Baixada Santista area, located at $23^{\circ} 50^{\prime} \mathrm{S}$ and $46^{\circ} 30^{\prime} \mathrm{W}$, comprises an important aquatic system and sites the biggest port of South America, a larger industrial pole, and urban centers with thrilling tourist activities. The study was carried out in the following parts of the aquatic system: the Santos (B) and Sao Vicente channels (A) and the Santos Bay (Figure 1). The port installations with a broad range of activities and sources of metal contamination are located at the Santos Channel. The main cities in the area are Santos, Cubatão and São Vicente, located at São Vicente Island and in the continent, with a total population around one million of residents (IBGE, 2020), but which increases by one third during summer. The aquatic estuarine system is a daily receptacle for urban, domestic and industrial effluents and essentially the urban domestic discharge is made by the submarine emissary of sewage of Santos with exit located near the 


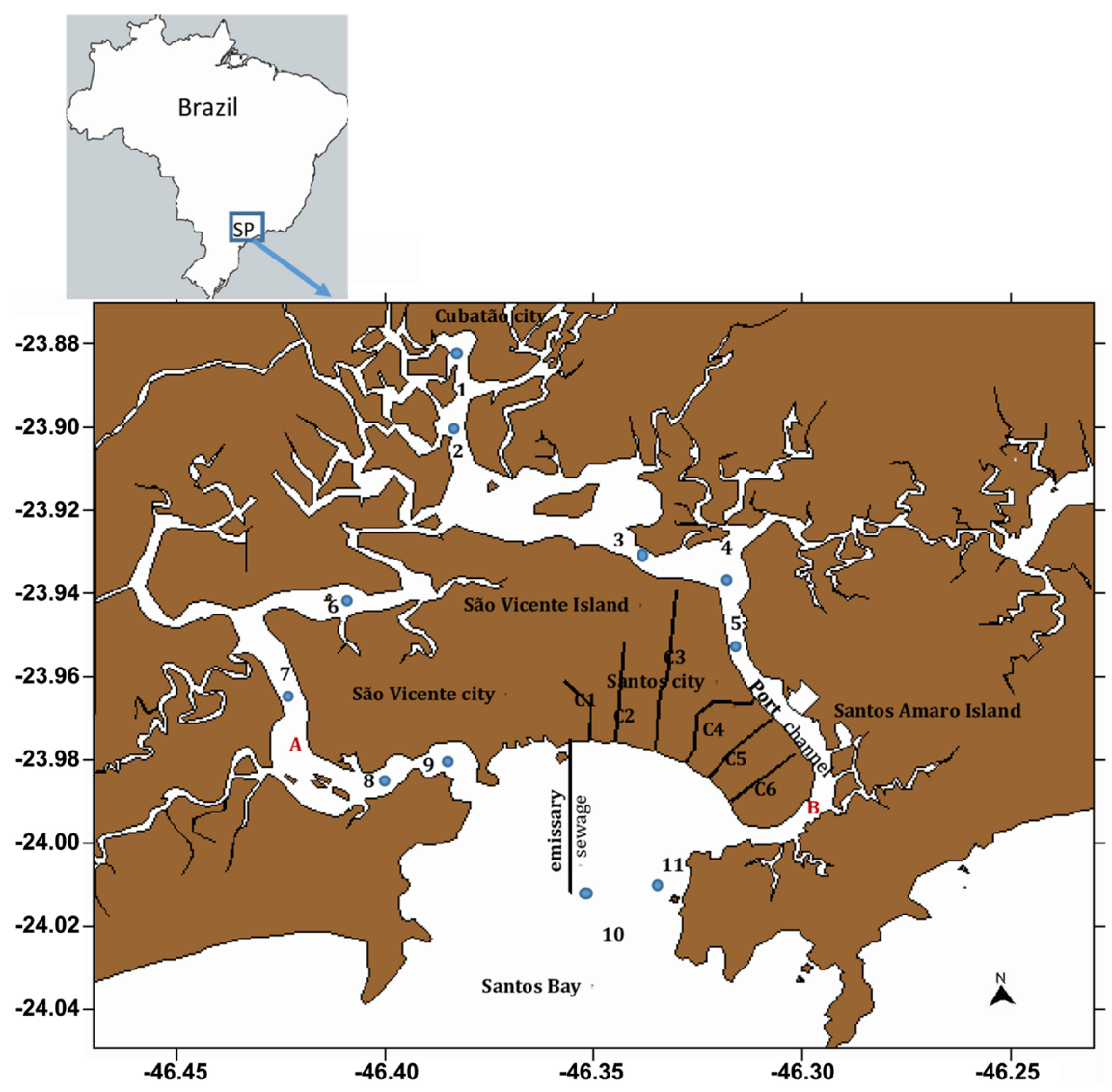

Figure 1. Study area. Sampling stations (1 - 5) in Santos Channel (A), stations 6 - 9 in São Vicente Channel (B) and stations in Santos Bay (station 10 near the submarine emissary of urban sewage) and 11. Pluvial drainage channels of Santos city (C1-C6). Estuarine system of Santos-São Vicente and Santos Bay, São Paulo, Brazil.

station 10. This submarine emissary of sewage is from 1978, and the tabulation is located at around $12 \mathrm{~m}$ depth. The collected domestic sewage is disposed in the sea by a submarine emissary. There is also a system of rainwater capture and drainage by mean of artificial channels along the Santos City that reach the Santos Bay showing in Figures 1(C1-C6).

\subsection{Sampling and Analyses}

The sampling activities were performed in the summer (February, 2001) and during respective periods of spring and neap tides. Eleven points in different sectors of the aquatic system were sampled. The stations 1 to 5 were located in the Santos channel, the stations 6 to 9 in the Sao Vicente channel, the station 10 was around an outfall of a submarine emissary, and the station 11 was taken as a referential location not polluted (Figure 1). Surface and bottom water column samples were collected using Niskin Hydrobios ${ }^{\circledR}$ polycarbonate bottles hoisted in a steel crane with a nylon cable. The samples were filtered through $0.45 \mu \mathrm{m}$ membrane, GF/F Whatmann ${ }^{\circledR}$, were acidified with $30 \% \mathrm{HCl}$ (suprapur Merck ${ }^{\circledR}$ ) to reach $\mathrm{pH} \sim 2$ and stored in plastic bottles. Temperature was measured "in situ" 
using digital thermometers with precision of $\pm 0.02^{\circ} \mathrm{C}$ and salinity was determined using Beckman ${ }^{\circledR}$ Industrial Salinometer, model RS-10C ${ }^{\circledR}$ with precision of \pm 0.001 . Dissolved oxygen was measured by titration using Winkler method as described in Grasshoff et al. (1983), using a Metrhohm ${ }^{\circledR}$ burette, with a precision of $0.02 \mathrm{~mL} \cdot \mathrm{L}^{-1}$. The $\mathrm{pH}$ measurements were performed using a radiometer ${ }^{\circledR}$ pHmeter with precision of \pm 0.01 . Prior to use all the items employed for sampling, filtration and sample storage were washed with diluted hydrochloric acid ( $\mathrm{pH} 2, \mathrm{HCl}$ suprapur ${ }^{\circledR}$, Merck), and then rinsed with Milli-Q water. Samples filtrations were carried out on board of the research vessel "Veliger II" of Oceanographic Institute-São Paulo University.

Despite high percentage of organic matter presence in water, the determinations of copper by CCSA was less affected than measurements by PSA using a mercury electrode (Riso et al., 1997a), the samples were submitted to UV pre-treatment to eliminate the excess of organic matter. Copper determination was performed by chronopotentiometric stripping method (constant current stripping analysis-CCSA) using a rotating gold disk electrode (Riso et al., 1997a), and with analytical precision of $2 \%$ and detection limit of $0.2 \mathrm{nM}$. Cadmium determination was carried out by another chronopotentiometric stripping method (potentiometric stripping analysis-PSA), using a rotating mercury disk film electrode (Riso et al., 1997b), and with analytical precision of $2 \%$ and detection limit of $0.01 \mathrm{nM}$. Table 1 summarizes the laboratory electrochemical conditions of the method applied for metal analysis (Waeles et al., 2004).

Table 1. Eletrochemical conditions of PSA and CCSA methods.

\begin{tabular}{|c|c|c|}
\hline Method & PSA (Cd) & $\operatorname{CCSA}(\mathrm{Cu})$ \\
\hline Working electrode & Mercury film & Gold disk electrode \\
\hline Deposition potential & -1200 & -350 \\
\hline $\begin{array}{c}\text { Versus Ag/AgCl 3M (mV) } \\
\text { Angular velocity (rpm) }\end{array}$ & 4130 & 4130 \\
\hline Deposition time (min.) & 15 & 5 \\
\hline Stripping & Chemical oxidation & Applied current of $2 \mu \mathrm{A}$ \\
\hline Reproducibility $(\mathrm{n}=9)$ & $4 \%$ (at $0.1 \mathrm{nM}$ level) & $2 \%$ (at $3.1 \mathrm{nM}$ level) \\
\hline Precision $(n=6)$ & $7 \%$ & $4 \%$ \\
\hline Detection limit & 0.01 & 0.017 \\
\hline
\end{tabular}

Weales et al. (2004).

\section{Results and Discussion}

\subsection{Physical and Chemical Characteristics of Study Area}

The hydrodynamic of the system is dominated by semi-diurnal tides, was influenced during neap tide by fluvial inputs of fresh water which flowing through the Santos and the Sao Vicente channels towards the Santos Bay. During spring tide more saline water was driven through the Bay to upstream the channels. The water movement in central part of the Santos Bay depends on prevailing 
currents. Usually, it displays a counter clockwise circulation during ebb tide and a predominant movement from the coastal region, in the flood tide (Harari \& Camargo, 1995).

The average values of water temperature during spring and neap tides were $26.98^{\circ} \mathrm{C} \pm 0.97^{\circ} \mathrm{C}$ to $28.74^{\circ} \mathrm{C} \pm 0.56^{\circ} \mathrm{C}$, respectively, these values which is characteristic of the aquatic system during summer season. The temperature in spring tide varied from $26.00^{\circ} \mathrm{C}$ to $28.90^{\circ} \mathrm{C}$ and in neap tide from $27.50^{\circ} \mathrm{C}$ to $29.50^{\circ} \mathrm{C}$, slightly highest than the values observed by Moser et al. (2005), in observation in the Santos-São Vicente estuary spring and neap tides with a range of $25.5^{\circ} \mathrm{C}$ to $28.1^{\circ} \mathrm{C}$ and $27.1^{\circ} \mathrm{C}$ to $28.3^{\circ} \mathrm{C}$ respectively, in summer 2000 . The salinity values were higher in spring tide, with variation from $26.40-34.71$, while in neap tide, the limits were lower (23.55 - 33.84) (Figure 2(a) and Figure 2(b)), and higher than the range of 26.6 - 33.5 and 29.6 and 32.6 - 32.6, in the spring and neap tides respectively, observed by Moser et al. (2005). Exception was observed in the inferior limit obtained in the neap tide, maybe in function of the rainy day in the sampling. The highest values of the maximum in this study is

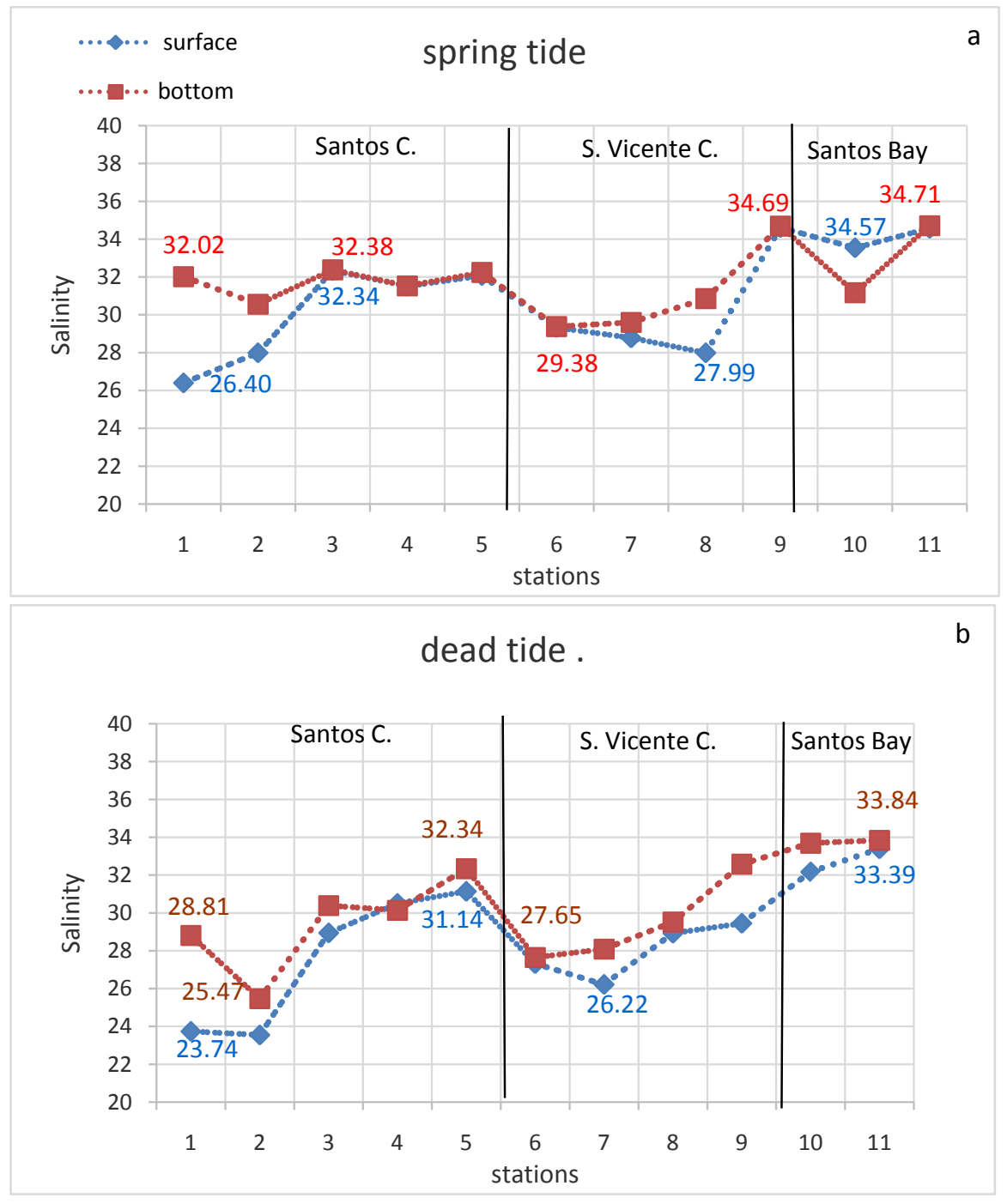




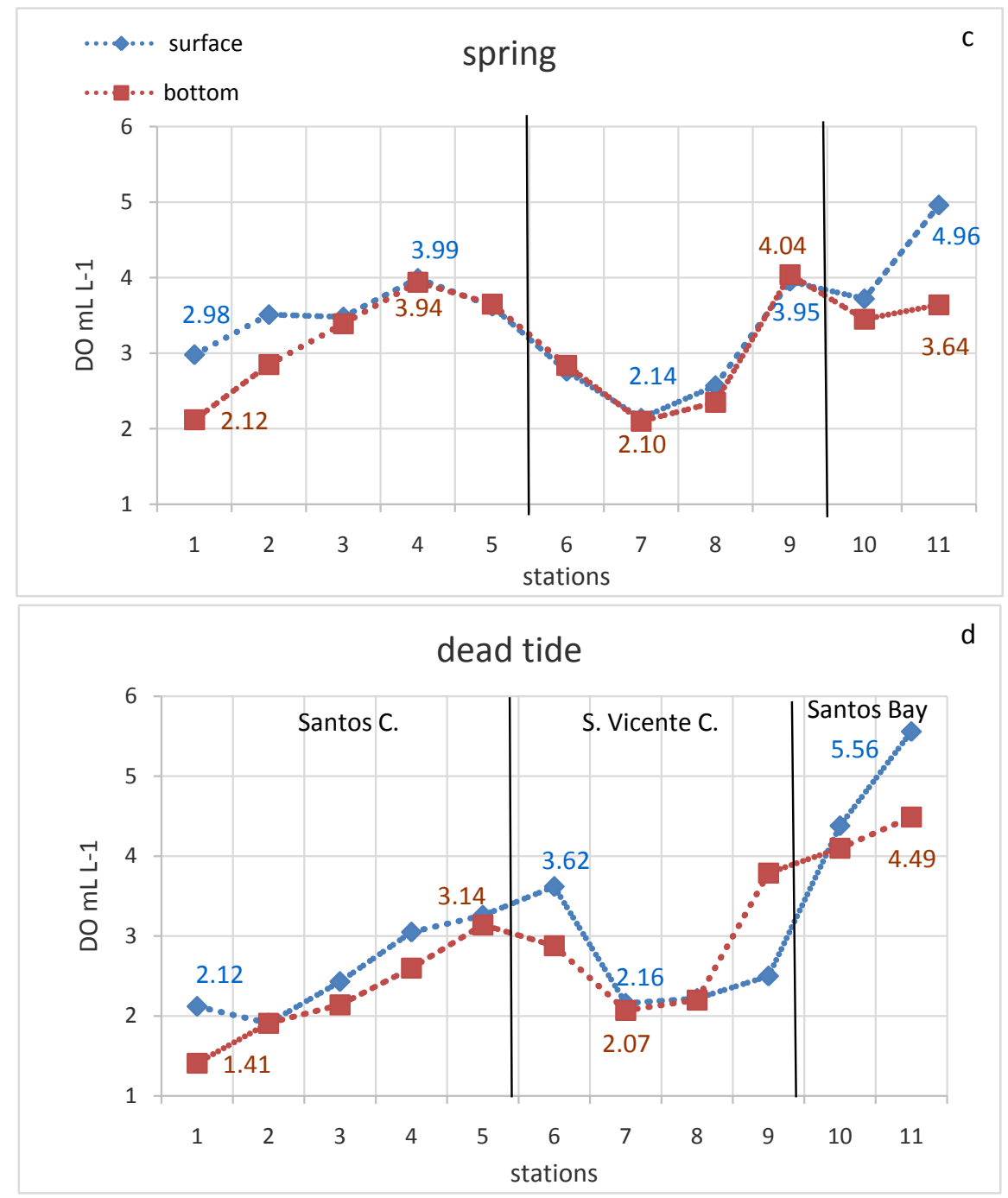

Figure 2. Distribution of salinity in spring tide (a) in dead tide (b) and dissolved oxygen in spring tide (c), in dead tide (d) in Santos-São Vicente estuary and Santos Bay, 2001.

associated to the sampling in the Bay of Santos, differently of the cited authors, which the study was limited to the estuarine channels.

The lowest $\mathrm{pH}$ values were detected in the Santos and São Vicente channels compared to the Santos Bay, and the values ranged from 7.74 to 8.32 and from 7.44 up to 8.43 during spring (average $8.11 \pm 0.17$ ) and neap (average $7.82 \pm$ 0.27 ) tides, respectively. The salinity and $\mathrm{pH}$ values increased toward the Bay, reflecting the mixing of fluvial and marine water (South Atlantic oceanic water) in the aquatic system changing the buffer characteristic of the seawater $(\mathrm{pH} \sim 8)$ to lowest values proper of the estuarine waters that offer more risk to the balance of the system. The Pearson correlation $(p<0.05)$ were significant among salinity and $\mathrm{pH}$ in the neap tide $(\mathrm{r}=0.87)$. The stations located in the channels, close to an industrial site and shantytowns presented low values of dissolved oxygen in both periods, spring tide ( 2.10 to $2.76 \mathrm{~mL} \cdot \mathrm{L}^{-1}$ ) and neap tide (2.07 to 3.62 $\left.\mathrm{mL} \cdot \mathrm{L}^{-1}\right)$. The general, the ranges were 2.10 to $5.46 \mathrm{~mL} \cdot \mathrm{L}^{-1}$ in spring tide and 1.41 
to $5.56 \mathrm{~mL} \cdot \mathrm{L}^{-1}$ in neap tide. The hypoxic conditions were observed in the station 1, near the Cubatão industrial pole, followed by the points at São Vicente Channel, characterized as a shallow area, with reduced hydrodynamic influence. More oxygenated conditions in water column were observed in the Santos Bay (Figure 2 (c) and Figure 2(d)). The associated data of $\mathrm{pH}$ and dissolved oxygen values showed significant correlation $(\mathrm{r}=0.90, \mathrm{p}<0.05)$ where the $\mathrm{pH}<8$ and $\mathrm{DO}<3.0$ $\mathrm{mL} \cdot \mathrm{L}^{-1}$ indicating hypoxy more sharp in water during neap tide, in this study.

In this context, the most stable condition is observed close to the Santos Bay with respect to environmental parameters considering that this area is under greater marine dominance and intense water movement that ensures conditions of oxygenation, high salinity and $\mathrm{pH}$ that showed higher and more stable values (8.20 - 8.43), except at the place of freshwater input by sewage by the submarine outfall (st. 10) that showed, in surface water in the central part of the Bay, values from 8.04 to 8.14 associated to low relative values of salinity (32.17 to 33.54 ). The station 10 (near the mouth of submarine emissary of urban sewage) showed the influence of the fresh water input associate to the sewage system of the Santos city.

The two estuarine Channels, Santos and São Vicente show greater variation in salinity and, consequently, in $\mathrm{pH}$ values, reflecting a risk of environmental imbalance and resilience answer in the face of major environmental changes. The dissolved oxygen values evidenced the points with the highest organic load, which is closely to the dumping of manure, low circulation and consequent difficulty in renewing water (st.1), which in the conditions of neap and spring tides demonstrate that the system has different responses to dilution and renewal of water properties. Knowing this environmental situation, now it is possible to observe the distribution of trace metals in view of the environmental rhythm in this frontier with ocean, submitted to strong anthropogenic influence.

\subsection{Dissolved Copper and Total Cadmium in Water}

The dissolved copper and total cadmium in water, in general presented concentrations from 6.4 to $45.4 \mathrm{nM}$ and from 0.35 to $2.64 \mathrm{nM}$, respectively. The details for the sector are presented in Table 2.

Average values of copper $(25.5 \pm 10.7 \mathrm{nM})$ in the Santos Channel (stations 1 5 ) was higher than in the other sectors. It represented almost twice the average

Table 2. Dissolved copper and cadmium concentrations obtained at Santos Bay, São Vicente and Santos Channels in summer 2001-São Paulo, Brazil.

\begin{tabular}{ccccc}
\hline $\begin{array}{c}\text { Metal } \\
(\mathrm{nM})\end{array}$ & Santos Channel & $\begin{array}{c}\text { São Vicente } \\
\text { Channel }\end{array}$ & Emissary & Santos Bay \\
\hline $\mathbf{C u}$ & $25.5 \pm 10.7$ & $14.1 \pm 5.8$ & $15.9 \pm 3.9$ & $12.4 \pm 2.3$ \\
Range & $(14.1-45.4)$ & $(6.4-26.4)$ & $(11.4-21.5)$ & $(8.6-14.5)$ \\
$\mathbf{n}$ & 20 & 10 & 4 & 4 \\
Cd & $1.35 \pm 0.70$ & $0.90 \pm 0.65$ & $0.67 \pm 0.15$ & $0.77 \pm 0.16$ \\
Range & $(0.41-2.64)$ & $(0.35-2.55)$ & $(0.52-0.89)$ & $(0.51-0.92)$ \\
$\mathbf{n}$ & 20 & 10 & 4 & 4 \\
\hline
\end{tabular}


value for in the São Vicente Channel (stations 6 - 9) which was similar to the level observed in the Santos Bay. The lowest value of copper was obtained in the referential station $11(12.4 \pm 3.9 \mathrm{nM})$, located at the Santos Bay, but the limit of variation observed considering all stations area was higher than that observed by Monbet (2001) (0.1 - 17.3 nM) in the French coast, while Hatje et al. (2003) that found in Port Jackson (Australia), an average around $26.5 \mathrm{nM}$.

Similarly to copper, higher average level of cadmium was observed in the Santos channel ( $1.35 \pm 0.7 \mathrm{nM})$, stations 1 - 5, when compared to values found in the Sao Vicente Channel (stations 6 - 9) and at the Santos Bay (stations 10 and 11). The reference station 11 displayed cadmium levels $(0.77 \pm 0.16 \mathrm{nM})$ higher than the maximum concentration observed in other coastal zones by Monbet (2001) (0.01 - $0.61 \mathrm{nM})$, even considering the effect of the hydrodynamic and dilution in the Bay. On the other hand, Hatje et al. (2003) observed an average higher than the obtained here, with a value corresponding to $3.55 \mathrm{nM}$, above the limit observed in this study $(2.64 \mathrm{nM})$.

In this work, it was possible to observe higher values of copper and cadmium than the concentrations found at Lena estuary (Martin et al., 1993), and Amazon estuary (Boyle et al., 1982), both characterized as non-industrialized estuaries. The values were also higher than in the Gironda (Kraepiel et al., 1997) and the Seine estuaries (Chiffoleau et al., 1994), which receives industrial effluents. The water column of the Morlaix river (Monbet et al., 2001), influenced by agricultural activities, displayed smaller values for copper and cadmium than in the aquatic system of the Baixada Santista. Only copper concentrations from the Blanca Bay (Pucci, 1988; Severini et al., 2009) were higher than values found in this work. The obtained concentrations of dissolved copper and cadmium characterized the Baixada Santista aquatic system as one of most polluted in the world. Input of industrial, urban, domestic and port effluents represent the main contamination sources for copper and cadmium in the water column of the Santos and Sao Vicente channels and the Santos Bay (Table 3).

Table 3. Dissolved copper and cadmium concentrations obtained in coastal and estuarine waters.

\begin{tabular}{|c|c|c|c|}
\hline Estuary & $\mathrm{Cu}(\mathrm{nM})$ & $\mathrm{Cd}(\mathrm{nM})$ & System characteristics \\
\hline Lena river ${ }^{1}$ & $1.6-11.8$ & $0.02-0.20$ & Non industrialized \\
\hline Amazon river $^{2}$ & $2-24$ & $0.04-0.10$ & Non industrialized \\
\hline North Biscay Bay ${ }^{3}$ & $1.7-8.0$ & $0.11-0.26$ & Non industrialized \\
\hline Loire estuary (inner) ${ }^{3}$ & $8.0-21.2$ & $0.08-0.29$ & Agricultural activity \\
\hline Morlaix river ${ }^{4}$ & $0.6-19.0$ & $0.04-0.48$ & Agricultural activity \\
\hline Gironde river $^{5}$ & $6.2-21.2$ & $0.20-1.20$ & Lightly industrialized \\
\hline Seine river ${ }^{6}$ & $7.8-39.5$ & $0.31-1.96$ & Highly industrialized and urban center \\
\hline Blanca Bay ${ }^{7}$ & $26.7-50.3$ & $5.34-9.78$ & Highly industrialized and urban center \\
\hline This work & $6.4-45.4$ & $0.35-2.64$ & Highly industrialized and urban center \\
\hline
\end{tabular}

(1) Martin et al. (1993); (2) Boyle et al. (1982); (3) Waeles et al. (2004); (4) Monbet (2001); (5) Kraepiel et al., 1997; (6) Chiffoleau et al. (1994); (7) Pucci (1988). 


\subsection{Variation on Metal Distribution and Concentration According to Tide Regime}

The spatial distribution of dissolved copper and total cadmium in spring and neap tide in different sectors of the aquatic system are shown in Figures 3(a)-(d). Cooper and cadmium distribution in the aquatic system should be affected by hydrodynamic of the system during different tide regime as shown in Figure 3(a), Figure 3(b) for spring tide and Figure 3(c), Figure 3(d) for neap tide. In spring tide (Figure 3(a) and Figure 3(b)), it was observed for surface water that the highest concentration was observed in the station 3, of 32 and 2.52 $\mathrm{nM}$, respectively for cooper and cadmium in the Santos Channel followed by station 6, in the São Vicente Channel, in the inner part of the estuary and in station 10, in Santos Bay, above the sewage outfall. For bottom water, the highest values of dissolved metals, respectively 41.0 and $39.2 \mathrm{nM}$ for copper in stations 1 and 2 followed by $36.0 \mathrm{nM}$ in station 4 and of 1.53 and $1.48 \mathrm{nM}$ for cadmium in stations 1 and 2 followed by the highest value in station $4(2.64 \mathrm{nM})$ were observed, highlighting the latter value.

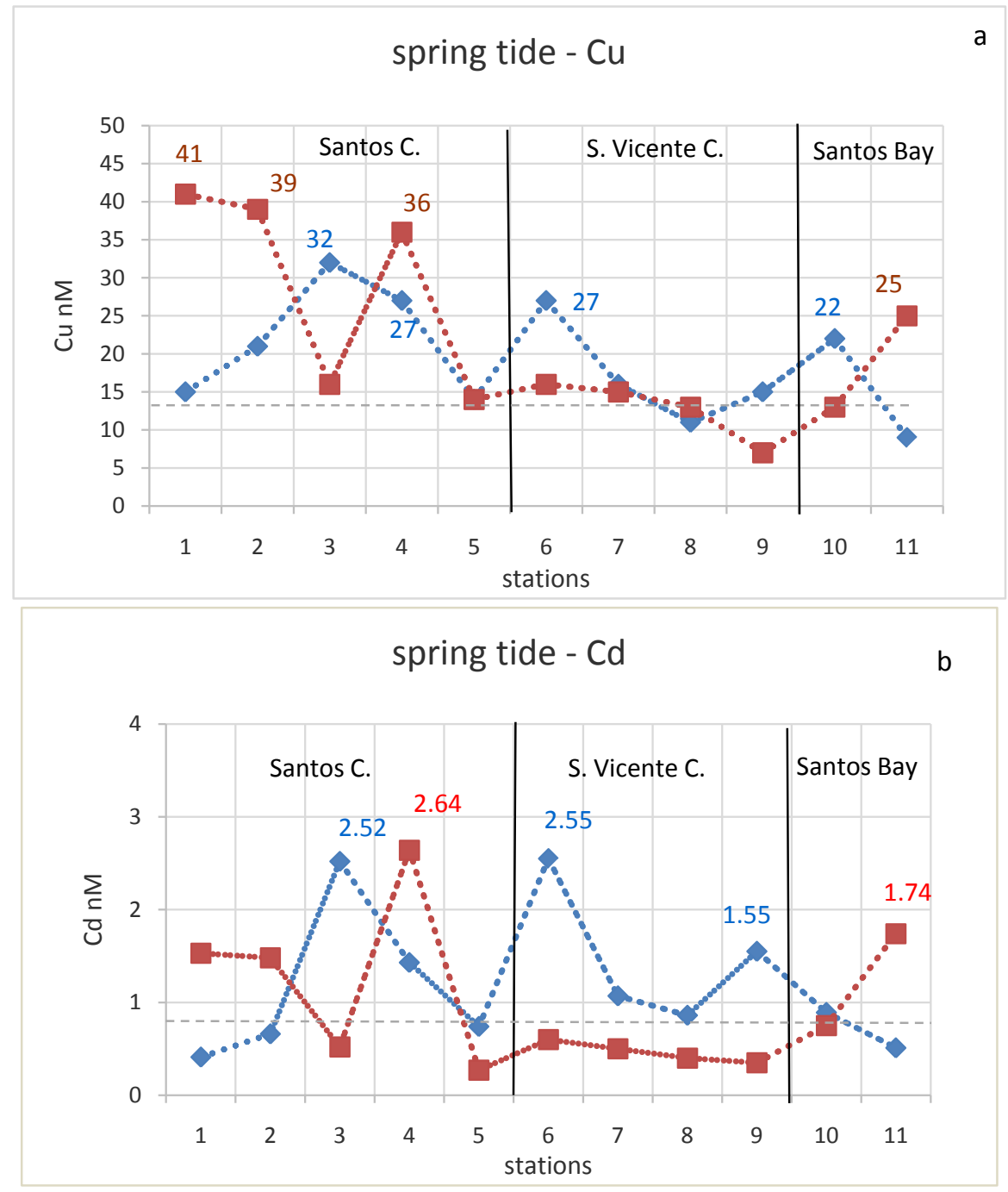




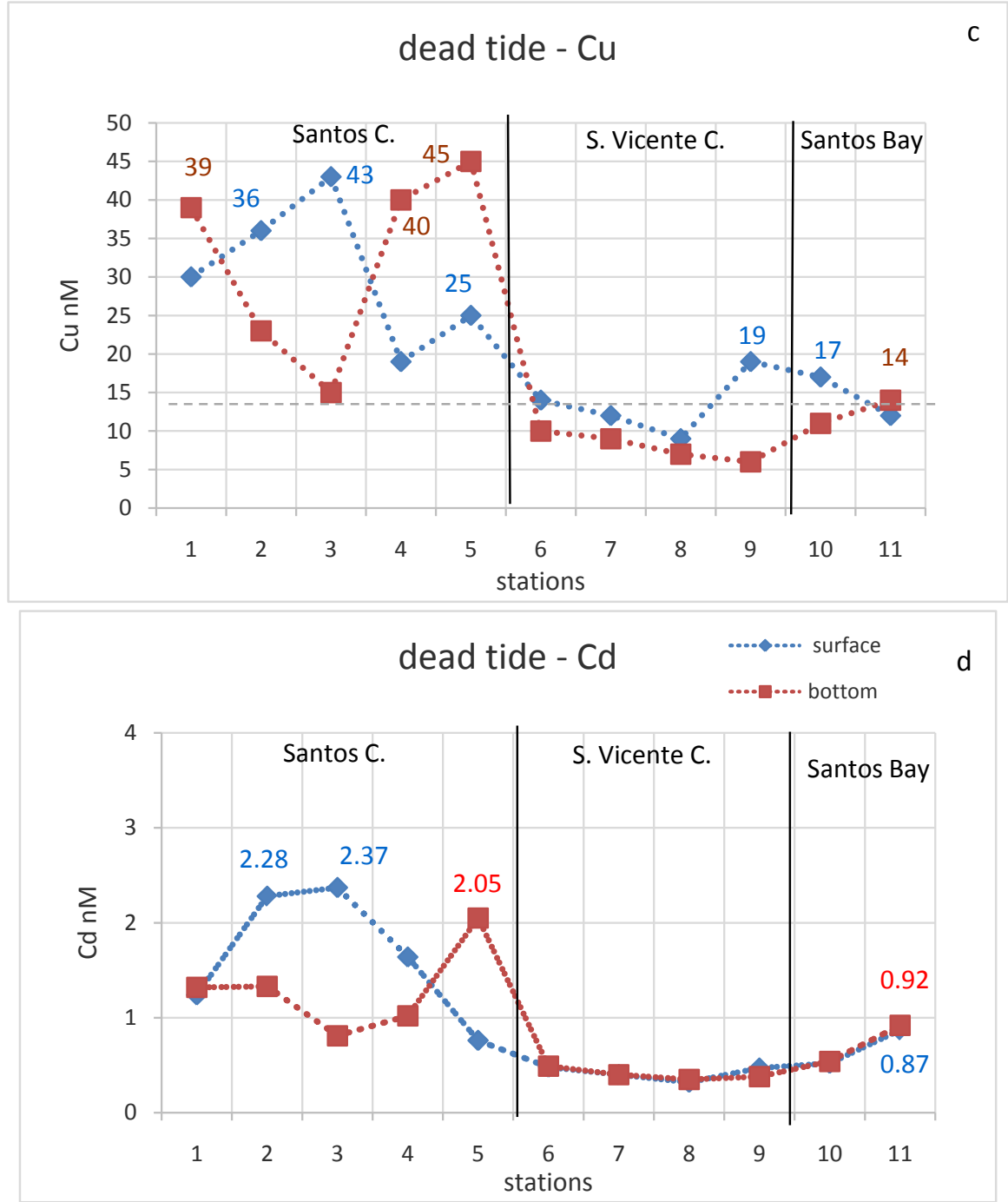

Figure 3. Spatial distribution of copper and cadmium in water considering the spring and neap tides influence in the estuarine system of Santos-São Vicente and Santos Bay in 2001, as a background for the most recent studies. Spring tide: copper (a), cadmium (b); Neap tide: copper (c), cadmium (d).

In the neap tide (Figure 3(c) and Figure 3(d)), in the surface water, the Santos Channels presented the highest concentrations within the stations 2 and 3 , presenting 36 and $43 \mathrm{nM}$ for cooper and 2.28 and $2.37 \mathrm{nM}$ for cadmium, respectively. The bottom water presented the same profile, i.e. the highest concentration in the Santos Channel, but the station 5 exhibited the highest value for copper and cadmium, 45.0 and $2.05 \mathrm{nM}$ respectively.

The submarine outfall displayed higher copper values during spring tide (maximum of $22 \mu \mathrm{M}$ ) related to dead tide in surface (Figure 3(a), Figure 3(c)) and, in relation to the station 11, showing a connection to the disposal of urban effluents. The referential station in the Santos Bay exhibited higher metal levels in bottom water in spring tide than in neap tide. The station 11 supposedly intended for reference showed increasing of $\mathrm{Cu}$ and $\mathrm{Cd}$ (Figure 3), in the bottom 
water in spring tide, maybe influenced by the sediment pollution under the vessel traffic and dredging of the port channel, also showing increase in cadmium in dead tide. São Vicente Bay (st. 9) showed slightly cadmium concentration in surface in spring tide and copper in dead tide, demonstrating the anthropogenic signals in this populated area. The station 6 is located in inner part of the system, under influence of the precarious housing and close to industrial pole, showing in surface waters in spring tide, elevation of copper and the highest cadmium concentration in surface water.

The copper is present in the domestic garbage, wastes in general, fungicides and algaecides used in swimming pools and in metal tubes and wires. The domestic use of copper is evident and the cadmium is used basically in the industrial activities. The copper is an important tracer of the urban occupation and domestic waste while the cadmium is an important tracer of the industrial activities.

In general, highest concentrations of copper and cadmium were observed in the Santos Channel, a region with intense port and industrial activity. Observing the general behavior of these trace metals (Figure 4) in relation to the spring and dead tide regime, it is possible to verify a higher median for copper in dead tide with more scattering in relation to spring tide, maintaining relation with the

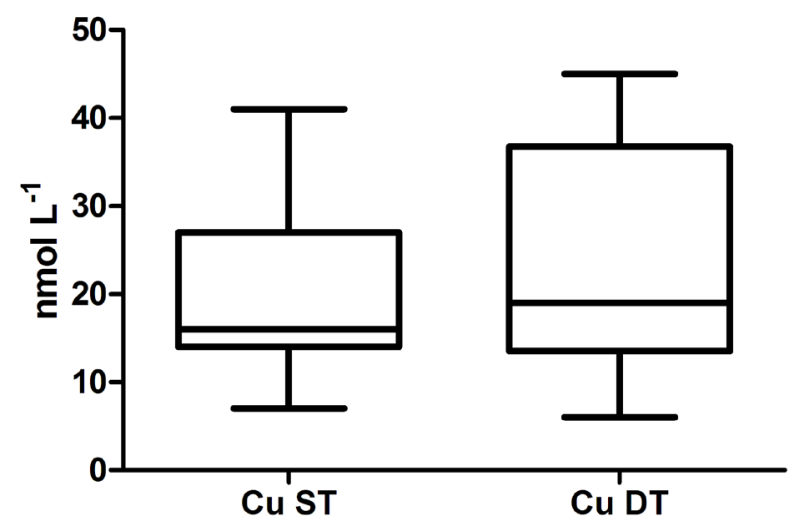

(a)

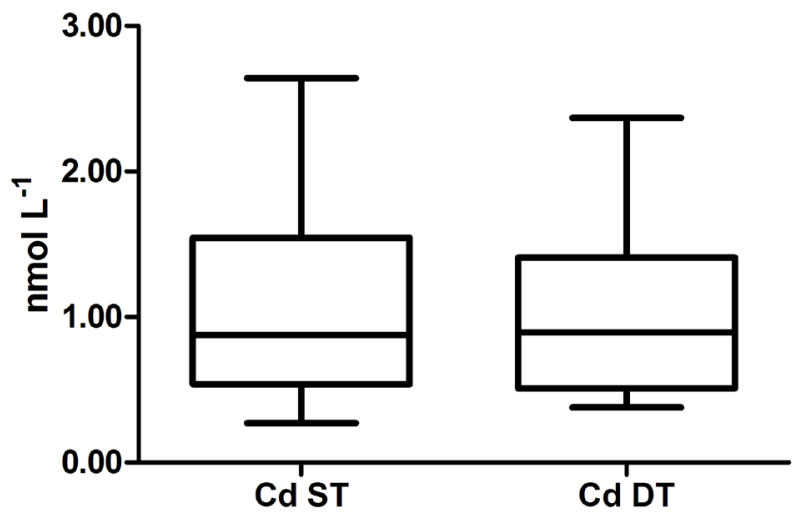

(b)

Figure 4. Box plot representations of the spring and dead tide concentration of cooper and cadmium in Santos-São Vicente estuary and Santos Bay, 2001. 
others environmental parameter, but showing, essentially relation with the main anthropogenic sources. On the other hand, cadmium showed similar median in both situation, showing more scattering under spring tide. The submarine outfall for domestic sewage evidenced the copper input while the industrial and port influence shows both metals input. Contaminated sediment probably influenced the cadmium concentration in the bottom water in the station 11, in the Santos Bay.

The results of this study show important varying concentration levels of copper and cadmium in the three sectors of the aquatic system. The stations in the Santos channel exhibited more dissolved metal contamination than the stations of the São Vicente channel and the Santos Bay. It indicates metal contribution from discharges related to port activities and industrial. The São Vicente Channel is contaminated by trace metals which come mostly from domestic effluents but also associated with industrial wastes. Nearby the submarine outfall copper and cadmium levels reflected simultaneous contribution from domestic and urban sewage discharge. It is inferred that cadmium was mainly affected by discharges from industrial effluents and copper by urban and domestic wastes.

At stations with high concentration of dissolved copper and cadmium the metal content in bottom sediments also presented elevated levels as previously observed by Siqueira (2003), Siqueira et al. (2005). As dredging is a regular activity in the Santos channel the resuspension of sediment associated trace metals also influences metal levels in water column.

In parallel to sources inputs magnitude, hydrodynamic conditions promoted important influence on variation of metal concentration in surface water that was more prominent for the Santos channel stations during neap tide. In those locations tides act with different intensities due to fresh water input, low depth of water column and the proximity of the sediments facilitating its re-suspension, and proximity with industrial effluent discharges.

In the Santos Bay the values also show difference in concentrations influenced by the tide regime which was more relevant in bottom water column during spring tide. The cadmium values found in the station 11 may be related to clandestine discharge of dredge material, because other recent sediment study showed information that contributed to this fact.

In relation to the methodology, the importance to obtain precise concentrations of heavy metals in the dissolved phase at this area is remarkable overall using electrochemical methods that are precise and dispense the pre-concentration treatments. It is possible because they are relatively simple in function of the recent development of electrodes. Considering the national data assembly, this study presents a first approach to showing precise information about the dissolved copper and cadmium associated to the oceanographic parameters in this region where mainly the total dissolved trace metal is analyzed with an other level of detection. Certainly, this it is not enough to comply with satisfy the recommendation of the environmental laws. The environmental studies in this region need to increment the understanding of the trace metal biogeochemical 
cycles to avoid risks to health due to bioacucumulation and biomagnification associated to the partition, chemical speciation and the biogeochemical ways followed by them, and surely, the dissolved forms play an important role in the environmental evaluation and protection.

To monitoring this area in relation to the trace metal contamination it is recommended to take in account besides biogeochemical aspects, the different sources presents in this complex area that presents intense hydrodynamic that could interfer the observed data, being expressed differently in relation to the seasonal period and also in spring and dead tide.

\section{Conclusion}

The evaluated levels of dissolved copper and total cadmium presented nonconservative behavior with salinity and independently of the spring and neap tide in water mainly evidencing the inputs from anthropogenic sources into the Baixada Santista aquatic system. The copper and cadmium concentration limits recommended by the Brazilian environmental law are related to the total cadmium and dissolved copper concentration in water representing a difference in the environmental role in bioavailable forms. In the Santos channel, effluent discharges are mainly related to industrial and port activities whereas in the Sao Vicente channel there is simultaneous contribution from industrial and domestic sewage. The high copper levels were observed as an indicator often associated with domestic and industrial effluents while the high cadmium levels were mainly related to industrial effluent discharges and sediment interaction with water column. Hydrodynamic mixing by tides regime promoted mechanism for metal concentration dilution. In the Santos Bay, the dilution of trace metals concentrations by mixing of saline and fresh water was an effective process with more evident the efficiency during spring tide due to the lower metal levels observed nearby the submarine outfall. On the other hand, it was also observed higher metal levels during period of neap tide in the channels. In addition, hydrodynamic conditions contributed for varying concentration levels between sampling stations. In the Santos Channel copper and cadmium levels were often related to higher values in surface water during neap tide and to higher values in bottom water column during spring tide. The contribution of trace metals in the coastal waters to the data bank is important, because the available knowledge about it is rare, the availability is mainly in relation to trace metals in sediment, having an imbalance of information, and these preterit data could contribute as a reference to current studies. However, the most important thing for nature is to maintain these elements in trace concentrations in all ecosystems and in this case to invest efforts to diminish the pollution in this region because these values classify this area as the most polluted in the world

\section{Acknowledgements}

We are grateful for the financial support of FAPESP (process n. 2000/00909-9). 
We thank D. Gilmar W. Siqueira for the collaboration in the preparation of the samples and also to Dr. Glaucia B. B. Berbel and Dr. Vitor G. Chiozzini and Cassia Cerezani de Andrade for collaboration with some final observations. We thank the crew of Veliger II R/V vessel during the sampling. We also thank the analytical facilities at the Institut Universitaire Européen de la Mer-UEM laboratory, in France.

\section{Conflicts of Interest}

The authors declare no conflicts of interest regarding the publication of this paper.

\section{References}

Azevedo, J. S., Braga, E. S. G., Silva de Assis, H., \& Oliveira Ribeiro, C. A. (2013). Biochemical Changes in the Liver and Gill of Cathorops spixii Collected Seasonally in Two Brazilian Estuaries under Varying Influences of Anthropogenic Activities. Ecotoxicology and Environmental Safety, 20, 220-230. https://doi.org/10.1016/j.ecoenv.2013.06.021

Boldrini, C. V., \& Pereira, D. N. (1987). Metais pesados na Baía de Santos e estuários de Santos e São Vicente-Bioacumulação. Ambiente (Revista Cetesb de Tecnologia), 1, 118-127.

Boutier, B., Chiffoleau, J. F., Auger, D., \& Truquet, I. (1993). Influence of the Loire River on the Dissolved Lead and Cadmium Concentrations in Coastal Waters of Brittany. Estuarine, Coastal and Shelf Science, 36, 134-145. https://doi.org/10.1006/ecss.1993.1009

Boyle, E. A., Huested, S. S., \& Grant, B. (1982). The Chemical Mass-Balance of the Amazon Plume; II Copper, Nickel and Cadmium. Deep-Sea Research, 29, 1355-1364. https://doi.org/10.1016/0198-0149(82)90013-9

Boyle, E. A., Sclater, F. R., \& Edmond, J. M. (1977). The Distribution of Dissolved Copper in the Pacific. Earth and Planetary Science Letters, 37, 38-54. https://doi.org/10.1016/0012-821X(77)90144-3

Braga, E. S. (2002). Bioquímica Marinha e efeitos da poluição nos processos bioquímicos (2nd ed.). Fundespa, São Paulo: Fundespa Press.

Braga, E. S., Bonetti, C. V. D. H., Burone, L., \& Bonetti Filho, J. (2000). Eutrophication and Bacterial Pollution Caused by Industrial and Domestic Wastes at the Baixada Santista Estuarine System-Brazil. Marine Pollution Bulletin, 40, 165-173. https://doi.org/10.1016/S0025-326X(99)00199-X

Bruland, K. W. (1980). Oceanographic Distributions of Cadmium, Zinc, Nickel and Copper in the North Pacific. Earth and Planetary Science Letters, 47, 176-198. https://doi.org/10.1016/0012-821X(80)90035-7

CETESB (Companhia de Tecnologia de Saneamento Ambiental) (2001). Sistema Estuarino de Santos e São Vicente (178 p.). São Paulo: Relatório técnico.

Chiffoleau, J.-F., Cossa, D., Auger, D., \& Truquet, I. (1994). Trace Metal Distribution, Partitionand Fluxes in the Seine Estuary (France) in Low Discharge Regime. Marine Chemistry, 47, 145-158. https://doi.org/10.1016/0304-4203(94)90105-8

CONAMA (Conselho Nacional de Maio Ambiente, Ministério do meio Ambiente) (2005). Resolução 357, de 17 de Março de 20005. Publicada no Diário Oficial da União DOU em 18/03/2005 (pp. 58-63). República Federativa do Brasil, Brasília, DF. Poder 
Executivo.

Fang, T.-H., \& Lin, C.-L. (2002). Dissolved and Particulate Trace Metals and Their Partition in a Hypoxic Estuary: The Tanshui Estuary in Northern Taiwan. Estuarine and Coasts, 25, 598-607. https://doi.org/10.1007/BF02804893

Fang, T.-H., Hwang, J. S., Hsiao, S. H., \& Chen, H. Y. (2006). Trace Metals in Seawater and Copepods in the Ocean Outfall Area off the Northern Taiwan Coast. Marine Environmental Research, 61, 224-243. https://doi.org/10.1016/j.marenvres.2005.10.002

Fostner, U., \& Wittimann, T. W. (1983). Metal Pollution in the Aquatic Environment (2nd Revised ed., 486 p.). Berlin: Springer Verlag.

Gao, X., Zhou, F., \& Chen, C. T. A. (2014). Review Pollution Status of the Bohai Sea: An Overview of the Environmental Quality Assessment Related Trace Metals. Environmental International, 62, 12-30. https://doi.org/10.1016/j.envint.2013.09.019

Grasshoff, K., Kremling, K., \& Ehrhardt, M. (1983). Determination of Trace Elements in: Methods of Seawater Analysis (3rd ed., pp. 253-263). Weinheim: Willey-Vch Verlag Press.

Harari, J., \& Camargo, R. (1995). Tides and Mean Sea Level Variabilities in Santos (SP), 1944 to 1989. Relatório Interno do Instituto Oceanográfico (Vol. 36, pp. 1-15). São Paulo: Universidade de São Paulo.

Hatje, V., Apte, S. C., Hales, L. T., \& Birch, G. F. (2003). Dissolved Trace Metal Distribution in Port Jackson Estuary (Sydney Harbour), Australia. Marine Pollution Bulletin, 26, 719-730. https://doi.org/10.1016/S0025-326X(03)00061-4

Hypolito, R., Nascimento, S. C., Gamito, D. C., \& Sumi, E. M. (2016). Ionic Behavior and Its Association with Waste Steel Industry in Mangrove Estuarine System of Santos-Cubatão/SP. Revista Geociências, UNESP, 35, 172-182.

IBGE Instituto Brasileiro de Geografia 2020. https://cidades.ibge.gov.br/brasil/sp/santos/panorama

Kim, B. S. M., Angeli, J. L. F., Ferreira, P. A. L., Sartoretto, J. R., Miyoshi, C., Mahiques, M. M., \& Figueira, R. C. L. (2017). Use of a Chemometric Tool to Establish the Regional Background and Assess Trace Metal Enrichment at Baixada Santista-Southeastern Brazil. Chemosphere, 166, 372-379. https://doi.org/10.1016/j.chemosphere.2016.09.132

Kim, B. S. M., Salaroli, A. B., Ferreira, P. A. L., Sartoretto, J. R., Mahiques, M. M., \& Figueira, R. C. L. (2016). Spatial Distribution and Enrichment Assessment of Heavy Metals in Surface Sediments from Baixada Santista, Southeastern Brazil. Marine Pollution Bulletin, 103, 333-338. https://doi.org/10.1016/j.marpolbul.2015.12.041

Kraepiel, A. M., Chiffoleau, J.-F., Martin, J.-M., \& Morel, F. M. M. (1997). Geochemistry of Trace Metals in the Gironde Estuary. Geochimica as Cosmochimica Acta, 61, 1421-1436. https://doi.org/10.1016/S0016-7037(97)00016-1

Martin, J.-M., Guan, D. M., Elbaz-Poulichet, F., Thomas, A. J., \& Gordee, V. V. (1993). Preliminary Assessment of the Distributions of Some Trace Elements (As, Cd, Cu, Fe, $\mathrm{Ni}, \mathrm{Pb}$ and $\mathrm{Zn}$ ) in a Pristine Aquatic Environment: The Lena River Estuary. Marine Chemistry, 43, 185-199. https://doi.org/10.1016/0304-4203(93)90224-C

Millward, G. E., \& Glegg, G. A. (1997). Fluxes and Retention of Trace Metals in the Humber Estuary. Estuarine, Coastal and Shelf Science, 44, 97-105. https://doi.org/10.1016/S0272-7714(97)80011-X

Monbet, P. (2001). Comportement des metaux (cuivre, plomb et cadmium) dans un estuaire a fort caractere agricole; bilan de masse xas de la baie de Morlaix (194 p.). Thesis $\mathrm{PhD}$, Université de Bretagne Occidentale.

Moser, G. A. O., Gianesella, S. M. F., Barreira-Alba, J. J., Bérgamo, A. L., Saldan- 
ha-Corrêa, F. M. P., Miranda, L. B., \& Harari, J. (2005). Instantaneous Transport of Salt, Nutrients and Suspended Matter and Chlorophyll-a in the Tropical Estuarine System of Santos. Brazilian Journal of Oceanography, 53, 115-127. https://doi.org/10.1590/S1679-87592005000200003

Pfeiffer, W. C., Fiszman, M., \& Lacerda, L. D. (1988). Heavy Metal Surveys in Brazilian Coastal Environments. In: U. Selinger, L. D. Lacerda, \& S. R. Patchineelam (Eds.), Metals in Coastal Environments of Latin America (297 p.). Berlin: Spring Verlag Press. https://doi.org/10.1007/978-3-642-71483-2 1

Pinheiro, J. P., \& van Leeuwen, H. P. (2004). Scanned Stripping Chronopotentiometry of Metal Complexes: Lability Diagnosis and Stability Computation. Journal of Electroanalytical Chemistry, 570, 69-75. https://doi.org/10.1016/j.jelechem.2004.03.016

Pucci, A. E. (1988). Heavy Metals in Water and Sediments of the Blanca Bay, Argentina. In U. Selinger, L. D. Lacerda, \& S. R. Patchineelam (Eds.), Metals in Coastal Environments of Latin America (pp. 9-15). Berlin: Spring Verlag Press. https://doi.org/10.1007/978-3-642-71483-2 2

Riso, R. D., Le Corre, P., \& Chaumery, C. J. (1997b). Rapid and Simultaneous Analysis of Trace Metals $(\mathrm{Cu}, \mathrm{Pb}$ and $\mathrm{Cd})$ in Seawater by Potentiometric Stripping Analysis. Analytica Chimica Acta, 351, 83-89. https://doi.org/10.1016/S0003-2670(97)00352-8

Riso, R. D., Monbet, P., \& Le Corre, P. (1997a). Measurement of Copper in Seawater by Constant Current Stripping Analysis (CCSA) with a Rotating Gold Disk Electrode. The Analyst, 122, 1593-1596. https://doi.org/10.1039/a705325h

Salaroli, A. B., Kim, B. S. M., Angeli, J. L. F., \& Figueira, R. C. L. (2018). Trace Elements in an Adjacent Channel of an Antropized Area: A Case Study of Baixada Santista, Southeastern Brazil. Ecotoxicology Environmental Contaminant, 13, 23-31. https://doi.org/10.5132/eec.2018.01.03

Severini, M. D. F., Botte, S. E., Hoffmeyer, M. S., \& Marcovecchio, J. E. (2009). Spatial and Temporal Distribution of Cadmium and Cooper in Water and Zooplankton in the Bahia Blanca Estuary, Argentina. Estuarine, Coastal and Shelf, 85, 57-66.

https://doi.org/10.1016/j.ecss.2009.03.019

Siqueira, G. W., Aprile, F. M., Mahiques, M. M., \& Braga, E. S. (2003). Determinação de matéria orgânica em sedimentos de fundo dos estuários de Santos/São Vicente e Baía de Santos, SP/Brasil. Congresso Brasileiro de pesquisas Ambientais e Saúde -CPBAS’2003, COPEC-Santos-21-23 Julho, 131-136. https://copec.eu/congresses/cbpas2003/proc/pdf/T101.pdf http://copec.eu/congresses/cbpas2003/proc/index.html

Siqueira, G. W., Braga E. S., Pereira, S. F. P., \& Silva, E. (2005). Distribuição do mercúrio em sedimentos de fundo no Estuário de Santos SP/Brasil. Rem-Revista Escola de Minas, 58, 309-316. https://doi.org/10.1590/S0370-44672005000400004

Tommasi, L. R. (1987). Poluição Marinha No Brasil: Síntese do Conhecimento. Publicação Especial do Instituto Oceanográfico, 5, 1-30.

Turner, A., Martino, M., \& Le Roux, S. M. (2002). Trace Metal Distribution Coefficients in the Mersey Estuary UK: Evidence for Salting Out of Metal Complexes. Environmental Science and Technology, 36, 4578-4584. https://doi.org/10.1021/es020075y

Waeles, M., Riso, R. D., \& Le Corre, P. (2005a). Seasonal Variations of Cadmium Speciation in the Penze Estuary, NW France. Estuarine, Coastal and Shelf Science, 65, 143-152. https://doi.org/10.1016/j.ecss.2005.06.002

Waeles, M., Riso, R. D., \& Le Corre, P. (2005b). Seasonal Variations of Dissolved and Particulate Copper Species in Estuarine Waters. Estuarine, Coastal and Shelf Science, 62, 
313-323. https://doi.org/10.1016/j.ecss.2004.09.019

Waeles, M., Riso, R. D., Maguer, J. F., \& Le Corre, P. (2004). Distribution and Chemical Speciation of Dissolved Cadmium and Copper in the Loire Estuary and North Biscay Continental Shelf, France. Estuarine, Coastal and Shelf Science, 59, 49-57. https://doi.org/10.1016/j.ecss.2003.07.009

Waeles, M., Riso, R. D., Maguer, J.-F., \& Le Corre, P. (2004). Distribution and Chemical Speciation of Dissolved Cadmium and Copper in the Loire Estuary and North Biscay Continental Shelf, France. Estuarine, Coastal and Shelf Science, 59, 49-57. https://doi.org/10.1016/j.ecss.2003.07.009

Waeles, M., Tanguy, V., Lespes, C., \& Riso, R. D. (2008). Behaviour of Colloidal Metals $(\mathrm{Cu}, \mathrm{Pb}$ and $\mathrm{Cd})$ in Estuarine Waters: An Approach Using Frontal Ultrafiltration (UF) and Stripping Chronopotentiometric Methods (SCP). Estuarine, Coastal and Shelf Science, 80, 538-544. https://doi.org/10.1016/j.ecss.2008.09.010

Waeles, M., Tanguy, V., Lespes, G., \& Riso, R. (2008). Behavior of Colloidal Metals (Cu, $\mathrm{Pb}$ and $\mathrm{Cd}$ ) in Estuarine Waters: An Approach Using Frontal Ultrafiltration (UF) and Stripping Chronopotentiometric Methods (SCP). Estuarine, Coastal and Shelf Science, 80, 538-544. https://doi.org/10.1016/j.ecss.2008.09.010

Windom, H., Byrd, J., Smith, J. K., Hungspreugs, M., Dharmvanij, S., Thumbakul, W., \& Yeats, P. (1991). Trace Metal Relationships in Estuaries. Marine Chemistry, 32, 177-194. https://doi.org/10.1016/0304-4203(91)90037-W

Yeats P. A., \& Loring, D. H. (1991). Dissolved ad Particulate Metal Distribution in the St. Lawrence Estuary. Canadian Journal of Earth and Science, 28, 729-742. https://doi.org/10.1139/e91-063

Zwolsman, J. J. G., \& Van Eck, G. T. M. (1999). Geochemistry of Major Elements and Trace Metals in Suspended Matter of the Scheldt Estuary, Southwest Netherlands. Marine Chemistry, 66, 91-111. https://doi.org/10.1016/S0304-4203(99)00026-2 